\title{
Teaching Religious Pluralism and Study of Religious Cultural Heritage in Bulgarian Universities
}

\author{
Georgeta Nazarska, Svetla Shapkalova \\ State University of Library Studies and Information Technologies, Sofia, Bulgaria \\ Email: georgeta.nazarska@gmail.com, sasch@abv.bg
}

Received 2 December 2013; revised 15 January 2014; accepted 23 January 2014

Copyright (C) 2014 by authors and Scientific Research Publishing Inc.

This work is licensed under the Creative Commons Attribution International License (CC BY).

http://creativecommons.org/licenses/by/4.0/

c) (i) Open Access

\begin{abstract}
The article aims to present good practices in academic religious education in Bulgaria. The paper provides an overview of religious education in Bulgarian universities, stating that it is currently mono-confessional both in private and in public universities. Non-confessional religious education is carried out only in the State University of Library Studies and IT (SULSIT) in Sofia. The introduced innovative training courses, teaching methods in the field of religious education, and new published teaching materials are commented. The paper gives examples of individual and group work of students. The last part of the article presents the results of two surveys with cluster of undergraduate and graduate students and data coming from qualitative research. The main conclusion is that learning outcomes from non-confessional religious education at the SULSIT are prerequisites for achieving the objectives of religious pluralism, for better training in cultural heritage, and to form an understanding to religious diversity.
\end{abstract}

\section{Keywords}

Academic Religious Education; Religious Pluralism; Cultural Heritage; State University of Library Studies and IT; Bulgaria

\section{Introduction}

The paper provides an overview of religious education in Bulgarian universities, stating that they have not teaching religious pluralism. Some theological faculties at the state universities are teaching Orthodoxy excluding other religions and denominations. Other denominations are also teaching in their own religious systems in a few private higher schools. 
An exception is the State University of Library Studies and Information Technologies (SULSIT) in Sofia, which develops curricula, giving knowledge of all world religions and of the five major religious denominations in Bulgaria (Orthodoxy, Catholicism, Protestantism, Islam, and Judaism). Within a few training courses in the last 9 years over 800 students from Bachelor and Master programs acquired knowledge of religion and developed skills in identifying and exploring religious cultural heritage. The paper uses quantitative and qualitative methods (interviews with students, surveys, discussion groups). In the beginning paper presents the structure and content of the innovative training courses, describes the issued teaching materials, and analyzes innovative methods of teaching, focusing on fieldwork. On the second place, the paper focuses on learning outcomes: gives examples of individual and group work of students; surveys are summarized.

\section{The Religious Education in the Bulgarian Universities and Higher Education Institutions}

The religious education in the Bulgarian state universities consists of the existing faculties of Theology. However only Orthodoxy is taught therein, and in the curricula and syllabuses the focus on the other religions and denominations is rare. In the private Higher Islamic Institute and Higher Theological Evangelical Institute Muslims and Protestants respectively educate and train within their religious systems. In the other state universities religious courses is taught in some of the humanitarian faculties and within the framework of particular courses on history, sociology and philosophy of religion [1]-[3].

\section{The Religious Education in State University of Library Studies and Information Technologies (SULSIT) in Sofia}

\subsection{Teaching Courses and Resources at the SULSIT}

Since 2004 in the State University of Library Studies and Information Technologies (SULSIT) non confessional religious courses is taught. They include students from different majors for bachelor's programs: Cultural and Historical Heritage Information Funds, Information Resources of Tourism, Archives and Documentary Studies, Print and Media Communications, Library Studies, Library and Information Management, and National Security and Cultural Heritage. Religious education is also taught in several master's programs.

The teaching is conducted within the framework of a block of courses oriented towards: history of religions, history of the religious denominations in Bulgaria (Orthodoxy, Catholicism, Protestantism, Islam, and Judaism), information funds of the religious centers, and religious holiday calendar. The teaching goals are: to obtain basic knowledge on the religious philosophy and practice, to develop skills, to create an attitude to the public events and processes, to understand and respect the religious differences and of the place and significance of the religion, to identify and research the religious cultural heritage.

In 2004, "St. Nicholas the Wonderworker" university chapel was consecrated. Currently it is used as a place of classes, religious services for important Christian holidays are held therein, and a rich library is collected.

The lecturers maintain contacts of many years with a number of religious institutions and NGOs, which representatives are often invited to be both guests and lecturers at various forums: the Holy Synod of the Bulgarian Orthodox Church, the Sofia Theological Seminary, the Troyan Monastery, the Rila Monastery, the St. Mina Monastery, the Faculty of Theology at the Sofia University, the Catholic Apostolic Exarchate, the Sisters of the Eucharist Monastery, the St. Joseph Catholic Con-cathedral, the Papal Nuncio, a number of Protestant churches, the Mufti Head office, the Banya Bashi Mosque, the Sofia Synagogue, the Jewish Museum of History, the Organization of the Bulgarian Jews "Shalom", etc.

The prepared textbooks and teaching materials, written purposefully for the SULSIT students, play an important role for the training process: History of Religious Denominations in Bulgaria (textbook with CD, 2009), Vocabulary of Religious Terms, Concepts and Names (2012), Students' Digital Archive on Religious Cultural Heritage (2012), Religious Holiday Calendar (2013), and Religious Pluralism (2013). They follow the present novelties of the teaching methods in religious education, being focused on the applied knowledge, skills, and attitudes. Materials combine text, audio and visual materials, being an integral body of lectures, reading materials, questions, tasks and tests, vocabulary and illustrations, instead only texts for learning [4]-[6].

\subsection{Teaching Methods at the SULSIT}

SULSIT lecturers use various teaching forms and methods. The traditional forms (lectures, discussions, semi- 
nars, role games, etc.) are preferred, but recently guest lecturers (experts and theologians) also are invited. The non-class work forms include field work (individual and collective) in religious centers. Various methods are used for assessment and evaluation: tests, papers, inquiries, and checklists.

During 2012/2013 academic year the lecturers prepared and completed successfully two research projects, in which students from all BA and MA programs participated. The projects Study and Socialization of the Cultural Heritage of the Religious Denominations in Bulgaria (2012) and "Shared" Religious Cultural Heritage: Study and Socialization in the Conditions of Multicultural Dialogue (2013) are focused on the socialization of the religious cultural heritage of the Orthodox, Catholics, Protestants, Armenians, and Muslims in Bulgaria among SULSIT students, and to create religious tolerance. Project combines various teaching methods with an accent on the interactive ones: field work (collective and individual), team work, and lectures of teachers and experts.

During the last two years the students had the opportunities to meet a number of clergymen (Orthodox, Catholic, and Protestant), to visit religious sites and places (the Catholic Apostolic Exarchate, the Sofia Synagogue, the Banya Bashi Mosque), and to listen reputable experts (theologians, philosophers, and pedagogues).

The group field works performed in Pazardzhik (2012) and Kyustendil (2013) were extremely helpful. In Pazardzhik a group of 40 students, doctoral candidates and teachers performed observation, audio and video recording in the Orthodox Cathedral, the Armenian Apostolic Church, the United Church of God and of the Regional Museum of History. Discussions and conversations were held there with priests, museum workers and church trustees. The young people compared the rituals, customs, traditions and cultural heritage of the different religious communities, and they enriched their general knowledge. After their return they elaborated by team work multimedia presentations, which they presented during Methods for Study and Socialization of Religious Cultural Heritage in the Higher Education Institutions Seminar. The experts, doctoral candidates and students held discussion on the opportunities of the higher education to socialize and initiate the preservation of the religious cultural heritage in the country. An exhibition of student photos, taken during the field work, was opened during the seminar. The papers read and other materials from the students and doctoral candidates' individual work (inquiries, interviews, observations, presentations, and photos) were included in Students' Digital Archive on Religious Cultural Heritage [7].

The join field work ended with filling in surveys, which showed both the possibilities of this teaching method for obtaining knowledge, as well as for creating empathy to the cultural diversification, of respect to the religion, holy places and individual religiosity.

During the teaching process each student has an individual field work: to make a spot visit to an Orthodox religious center or to monitor and record the observation of a religious holiday, after which the student has to complete a checklist or inquiry with standard questions.

During 2012/2013 academic year 78 students from three majors passed individual field work. They studied 12 monasteries, 26 Orthodox churches and 2 chapels, and provided papers as result of the observation of a number of religious holidays: Palm Sunday, Easter, Ascension Day, St. George's Day, and many others. The analysis shows that the students meet no difficulties during their studies of the religious centers. They analyze the holiday through religious icons and frescoes, they comment on the behaviour of the congregation in the place of God.

\subsection{Outcomes from Religious Teaching at the SULSIT}

In the course of training process students complete surveys "at the entrance" and "at the exit".

At the beginning of each academic year the lecturers perform surveys with the $1^{\text {st }}-3^{\text {rd }}$ year students, both from the full-time and part-time. The survey aims at giving an idea of the level of religiosity of the young people and for the place of the academic education in this process.

The survey provides choice among provided answers, consisting of 7 questions. It is delivered on paper, and it is completed anonymously by the students within 10 minutes. The introduction part reviews the social background of the participants and the questions are grouped in two parts: 1 - 5 review and study the personal religiosity, and 6 - 7-the place of the education in this process.

The analyzed 30 surveys are mostly completed by women (77\%). The students are born in big towns (73.3\%) and they are rarely from small towns and villages. Two age groups are predominant: the young people 20 - 30 years of age, i.e. born in 1983-1993, and students grown during the 1990s, in a time of values crises.

The results from the survey show that the majority thereof $(60 \%)$ declare that the religion is important for 
them to "a certain degree". Another 30\% think that the religion plays no role whatsoever in their life (Figure 1). $66.7 \%$ of the participants state that not God, but material factors and other forces are in the base of the world development (Figure 2). This shows high level of secularity in thinking and lack of Christian views. The third and fourth questions are related to the communication between man and God through prayers and participation in holy mass. They, in addition to being obligations of the believer from any denomination, are also a fundamental marker for the existence of her/his personal religiosity. The answers from the survey show that $73.3 \%$ of the students do not pray and even are not aware of the essence and contents of the prayer and $33.3 \%$ have never attended worship and have no knowledge of confession and communion (Figure 3). The answers provided once again confirm that most of the people in Bulgaria declare themselves Orthodox only as a tradition, but not according their personal faith and beliefs. The answers of the fifth question provide strong confirmation of the observations for existence of secularization process, low religiosity, and replacing the faith with popular Christianity. The question is aimed at studying whether faith has external expression in charity work and care for sick, poor and disadvantaged people, and children; participation in religious foundations, associations, etc. Here the results are also unambiguous: $76.7 \%$ of the respondents state that they have "never" participated in similar activities, and only 20\% do that "sometimes". "Constantly" and "often" is the answer of only 3.3\% (Figure 4). The next two questions are related to the knowledge about the religion—-for the need thereof, for the information and communication channels, along which the knowledge reaches the students, for the effectiveness from the education in the SULSIT. According to the answers in the survey $70 \%$ of the students enroll in the higher education having a few ideas about the religion and religious attributes, acquired in the family and the high school. This explains why the ideas are reduced to the outside aspects of the religion, and why they are so incomplete and vague. The consequences from the years of atheistic totalitarian regime and from the political transition, marked with decline in the values' system and crises in the Bulgarian Orthodox Church, are in the answers of $20 \%$ of the students stated that they have knowledge of the religion. Although only $10 \%$ have stated that they have acquired base knowledge about the religion in the SULSIT, 90\% of the respondents say that the education there is useful for them in view of enriching their general culture and professional advancement.

In April-May 2013 we conducted a survey among students from $1^{\text {st }}-3^{\text {rd }}$ year students to examine the results of their education after the completion of the religious study. The survey covered 65 students, of which 38 female and 27 male, with predominant age group 19 - 25 years of age. Most of them have graduated from general education and vocational high schools $(49.2 \%$ and $43.3 \%)$. The main group is $1^{\text {st }}$ year students $(72.1 \%)$, followed by $2^{\text {nd }}$ year students $(19.7 \%)$ and $3^{\text {rd }}$ year students $(8.2 \%)$. The survey provides choice among limited answers, including 7 questions; four of them are with multiple choices.

According to the students prior to their enrollment in the SULSIT they had religious knowledge "to a certain degree”, obtained in the family (43.6\%), from the media (17\%) and from the high school (16\%). In this process representatives of the various religious communities were almost non-existent: $30 \%$ respond with "yes", 31\% with "no", and 58.6\% are "not sure". Summarizing what are the main consequences from the religious education

\section{Religion is important}

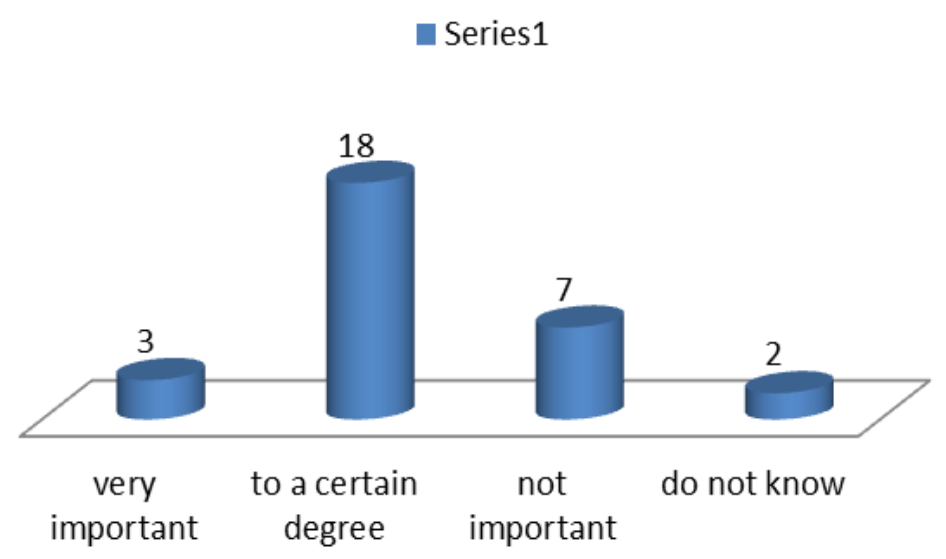

Figure 1. Survey of religiosity: importance of religion. 


\section{I think that}

- Series1

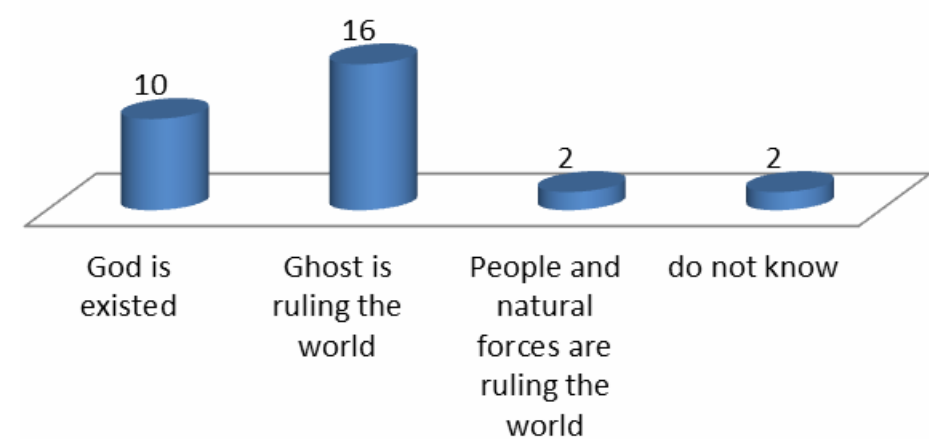

Figure 2. Survey of religiosity: religious believes.

\section{I pray}

- Series1

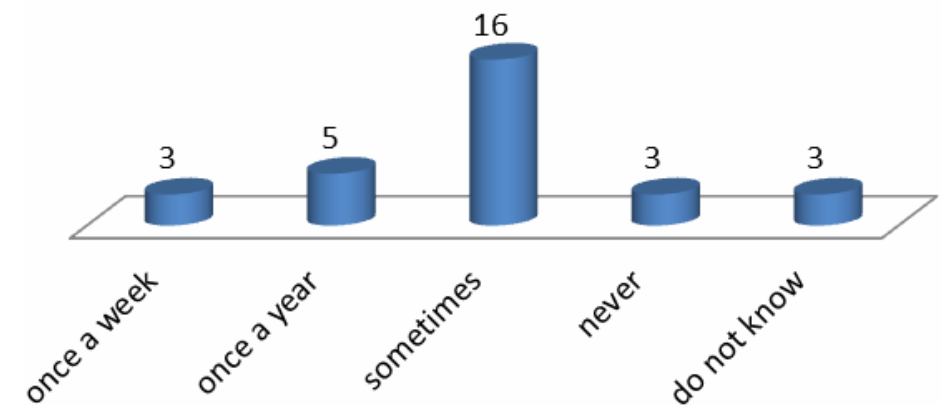

Figure 3. Survey of religiosity: religious practices, praying.

\section{I attend worships}

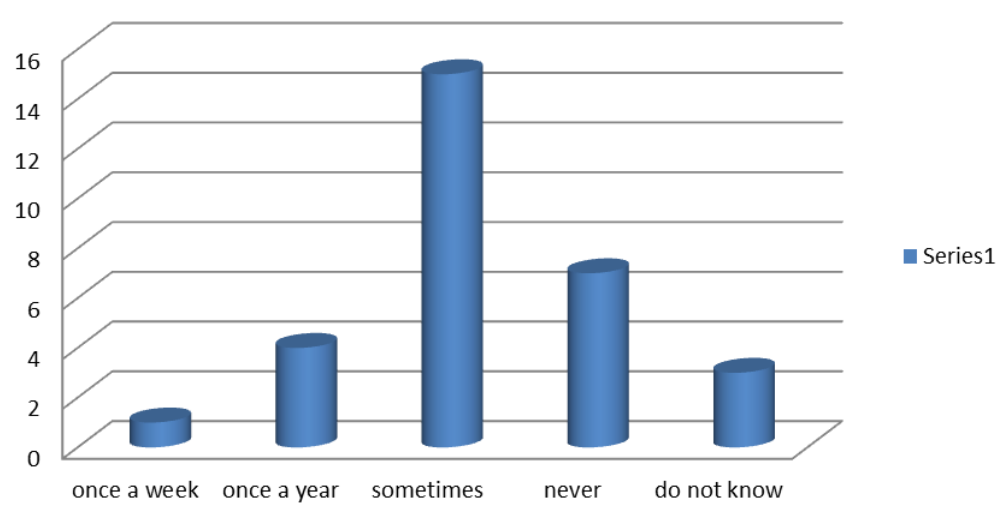

Figure 4. Survey of religiosity: religious practices, attendance of worships.

in the SULSIT, the students state: visit to religious sites and places (24.2\%), understanding of the religious rituals (21.2\%) and skills for comparing the religious communities (18.2\%). Very few are the students influenced to: read books on religion (10.1\%) or on history of the religions (8.1\%) (Figure 5). The answers of the next 
questions also provide insights in the results from the non-confessional religious training in highly secular environment. According to the results the students still do not pray, continue not to attend religious services and in other religious rituals, but they answer that they visit churches and temples (8.5\%), participate in collective group field work (20.1\%), listen with interest lectures of the teachers (25.7\%) and of external experts (20.1\%), participate in meetings with experts (16.7\%) and religious figures (13.9\%). The answers rejecting completely the benefit of the religious teaching are few (2.1\%). The customized prepared textbooks and teaching materials turn out to be especially useful in the training process: $85.7 \%$ of the students acknowledge this (Figure 6).

\section{Conclusions}

During the last 9 years more than 800 students in the SULSIT, both from bachelor's and master's programs, have obtained religious knowledge and they have acquired skills to identify and study the religious cultural heritage.

The analyses of the surveys confirm that the religious educational training in the higher education in Bulgaria is a difficult task, taking into consideration that: the target group consists of young people product of the consumer society, who have secular thinking; until their 20 - 25 years of age they have never been taught purposefully neither in the family, nor in the Bulgarian Orthodox Church and its clergy, nor in the high schools; the

\section{Main consequences from the religious education in SULSIT}

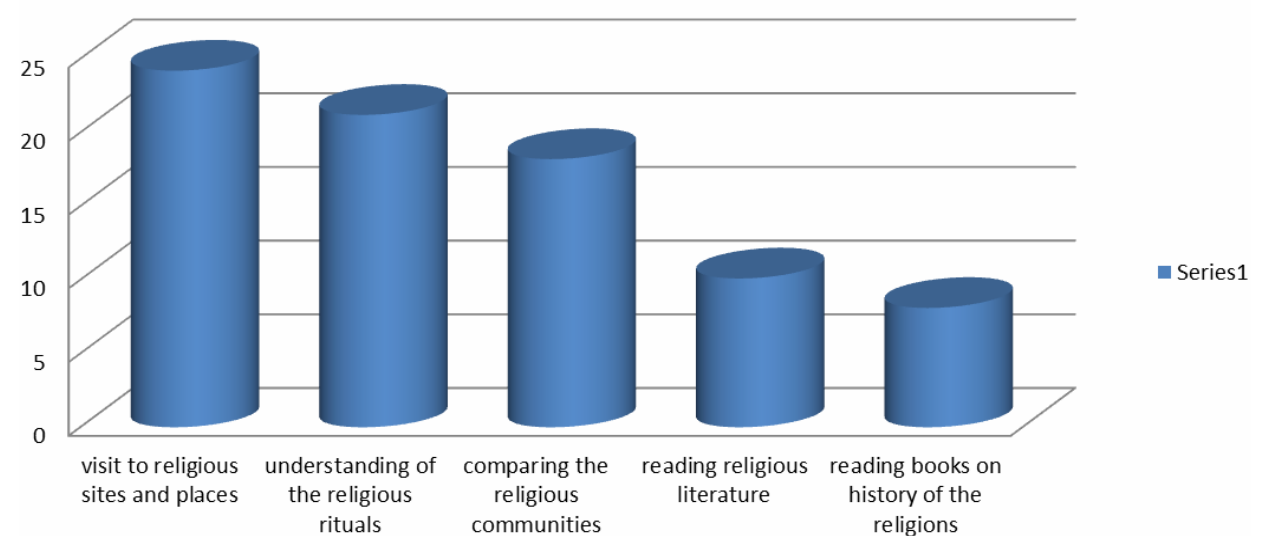

Figure 5. Survey of religious education at the SULSIT: educational results.

\section{After religious education at the SULSIT}

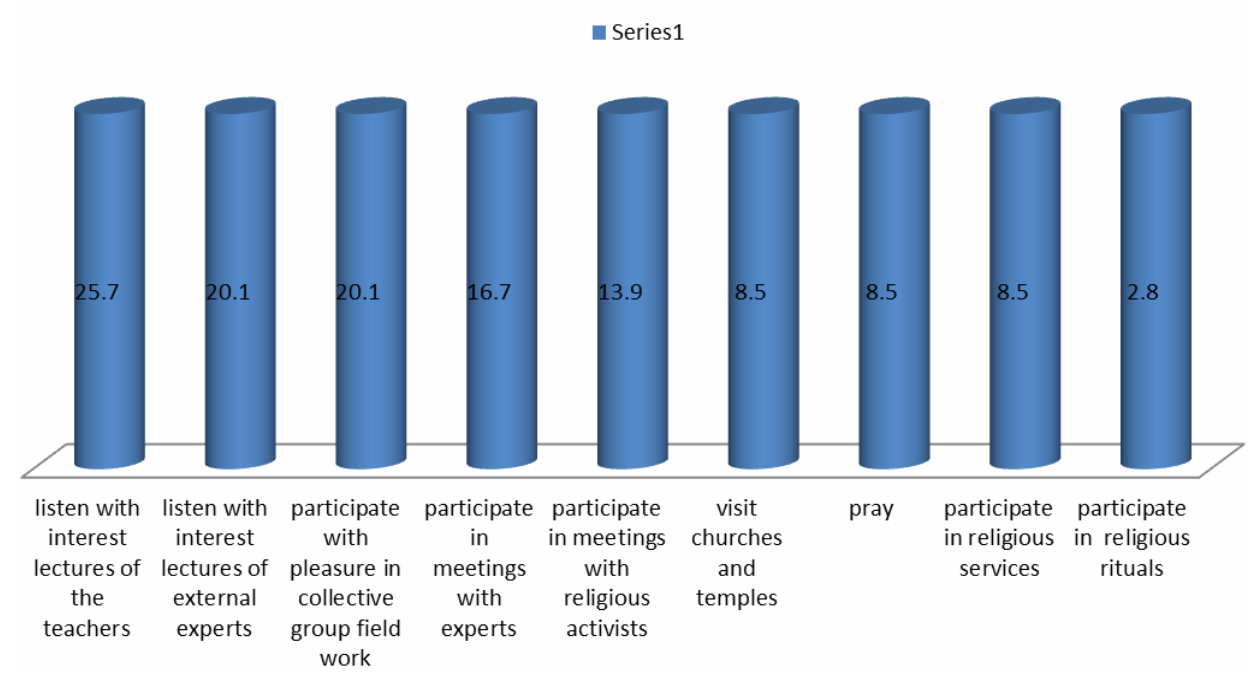

Figure 6. Survey of religious education at the SULSIT: religious results. 
public environment and secular educational tradition do not encourage such education, on the contrary-act against it.

Despite all these difficulties, the religious education is absolutely necessary for the young people to complete their general outlook, to develop their professional expertise and orientation in the post-modern situation. In particular circumstances this may lead to increasing of the level of personal religiosity, as long as these students have formed religiosity during the period of their training.

\section{Acknowledgements}

This article is financed by the Project BG-051PO001-3.3.06.0055 "Creating an Information Environment that Motivates and Provides Incentives for Young Researchers at the SULSIT" under Grant scheme "Support for Development of Doctoral and Post-doctoral Students, Graduates Pursuing Specialists Studies and Young Researchers" of the HRD Program co-financed from the ESF of the EU.

\section{References}

[1] Andonov, B. (2006) The Difficulties Experienced in Post-Communist Bulgaria in Relation to Religion Teaching. In: Schreiner, P. and Fr. Kraft, A.W., Eds., Good Practice in Religious Education in Europe. Examples and Perspectives of Primary Schools, LIT Verlag, Münster.

[2] Andonov, B. (2007) Religious Education in Bulgaria. In: Kuyk, E. et al., Eds., Religious Education in Europe. Situation and Current Trends in Schools, Oslo, 31-36.

[3] Denev, I. and Gross, E., Eds. (2004) Mezhdunaroden Religiozno-Pedagogicheski Simpozium v Balgaria. Religioznoto Obuchenie v Konteksta na Obshtoevropejskiya dom 25.-10.10. 2003. International Symposium on Religious Education Held in Bulgaria: Religious Education within the Context of the Common European Hous, Sofia.

[4] Nazarska, G. and Shapkalova, Sv. (2009) Istorija na Religioznite Denominatsii v Balgaria. Uchebnik s Kompakt-Disk. History of Religious Denominations in Bulgaria, Textbook \& CD, Za Bukvite-O Pismeneh, Sofia.

[5] Nazarska, G. and Shapkalova, Sv. (2012) Rechnik na Religiozni Poniatiya, Termini i Imena: Yudaizam, Hristiyanstvo, Islyam. Ucheben Rechnik. Vocabulary of Religious Terms, Concepts and Names: Judaism, Christianity and Islam, Teaching Resource, Za Bukvite-O Pismeneh, Sofia.

[6] Nazarska, G. (2013) Religiozen Pluralizam. Religious Pluralism, Textbook \& CD, Za Bukvite-O Pismeneh, Sofia.

[7] Nazarska, G., Ed. (2012-2013) Studentski Digitalen Arhiv po Religiozno Kulturno-Istorichesko Nasledstvo. Teaching Resource, Za Bukvite-O Pismeneh, Sofia. 